\title{
STORAGE CHARACTERISTICS OF SPIKES AND GRAINS OF BREAD
} WHEAT CULTIVARS

\author{
S. H. Cheyed ${ }^{1}$ \\ Assist. Prof. \\ A.Ch. Al-Fahad ${ }^{2}$ \\ A. S. Al-Rawi ${ }^{1}$ \\ Lecturer \\ Lecturer \\ ${ }^{1}$ Dept. of Field Crop Coll. of Agric. Engine. Sci. University of Baghdad, \\ ${ }^{2}$ Agric. Coll. University of Anbar \\ saddam.hakeem@coagri.uobaghdad.edu.iq
}

ABSTRACT

This study was conducted to identify the storage characteristics of spikes of five bread wheat cultivars (Abu-Ghraib3, IPA-99, Boohooth-22, Al-Rashid and Al-Wafeer). These spikes were gathered and compacted in cubic box $(25 \times 25 \times 25 \mathrm{~cm})$ with different weight masses $(0,3,6$ and $9 \mathrm{~kg}$ container $\left.^{-1}\right)$. A laboratory experiment was carried out in the Seed Technology Laboratory, Department of Field Crop Sciences, College of Agricultural Engineering Sciences-University of Baghdad. Results revealed significant differences among cultivars, masses levels and their interaction for all studied characters. Abu-Ghraib3 gave the highest mean of spikes number and less mean for the broken spikes and shuttered grains. While AlWafeer gave the highest mean of total grains weight resulted from spikes shuttering and grains space. However, Al-Rashid gave the highest mean of broken spikes, shuttered grains and replacement percentage in the container. Increasing the weight masses imposed on the gathered spikes in the container increased all studied characters. It can be concluded that the varieties were different in their spikes morphological characteristics as smaller spikes sizes the less losses resulted from spikes pressure.

Key wards: Triticum aestivum L., spikes breakage, spikes compacted, spike length.

جياد وآخرون

258-252:(1)51:2020 مجلة العلوم الزراعية العراقية

$$
\begin{aligned}
& \text { الصفات الخزنية لسنابل وحبوب اصناف من حنطة الخبز }
\end{aligned}
$$

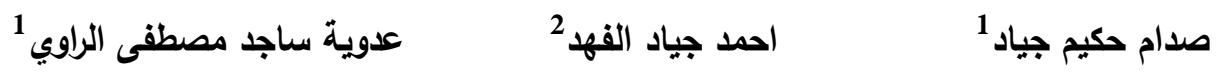

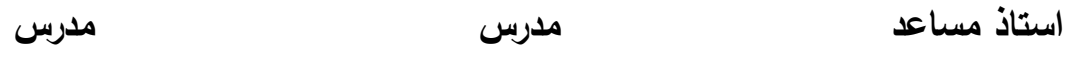

$$
\begin{aligned}
& \text { 1قسم المحاصيل الحقلية - كلية علوم الهندسة الزراعية- جامعة بغداد، } 2 \text { قسم المحاصيل الحقلية - كلية الزراعة ملاعيل } \\
& \text { جامعة الانبار }
\end{aligned}
$$

المستخلص

تهذف الدراسة لمعرفة الصفات الخزنية لسنابل خمسة اصناف من حنطة الخبز(ابو غريب واباء 99 وتحدي 22 والرشيا

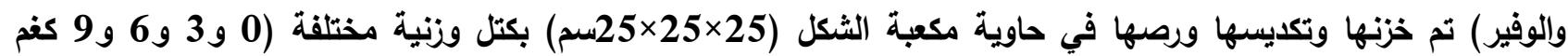
حاوية-1). نفذت التجرية في مختبر تكنولوجيا البذور التابع لقسم المحاصيل الحقلية في كلية علوم الهندسة الزراعية جامعة وداية بغداد. الشارت النتائج الى وجود فروقاً معنوية بين الاصناف وبين مستويات الكتل الوزنية المسلطة والتداخل بينهما في جميع الصفات المدروسة. اذ اعطى الصنف ابوغريب3 اعلى متوسط لعدد السنابل وادنى متوسط لنسبة السنابل المتكسرة والحبوب المتساقطة. في حين اعطى الصنف الوفير اعلى متوسط لوزن الحبوب الكلي الناتج من تفريط السنابل وحيز الحبوب. فيما اعطى الصنف الرشيد اعلى متوسط لنسبة السنابل المتكسرة والحبوب المتساقطة ونسبة الازاحة في الحاوية. وادت زيادة

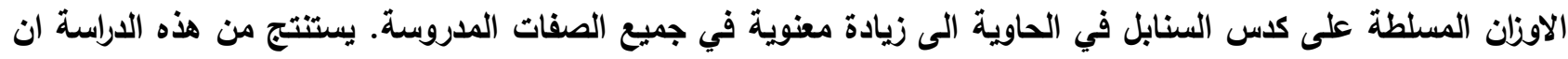
سنابل الاصناف تتباين في قابليتها للتكديس بسبب الاختلافات في صفاتها الظاهرية لاسيما حجم السنبلة. الكلمات المفتاحية: .Triticum aestivum L ، تكسر السنابل، رص السنابل، طول السنبلة. 


\section{INTRODUCTION}

Wheat (Triticum aestivum L.) is considered one of the most important field crops in terms of economic and strategic values as it supplies the major food for most of the world population $(9,16)$. The wheat acreage for 2019 was 220.4 million hectare with the total production 765.0 million tons (10). Wheat grains are considered the important source of carbohydrates (12), proteins and several minerals and fibers $(6,17,18)$. However, wheat world production in a continuous fluctuation due to the environmental factors, climatic changes and pests infection. Therefore, this cries must be overcomed via adoption of new management systems and an efficient storage for grains as source for case consumption. Safe storage of cereals crops is an essential factor to assure the supply of local foods (20). The success of storage method depends upon the targets of grains storage and plant species, besides the genetic effect on the grains storability. Moreover, there is physical and chemical effects e.g. moisture seed content, seed coat structure, temperature and gas exchange. The storage factor largely affects the seed quality as stored seeds subject to the deterioration. Results of many studies were revealed that the storage of crops seeds on their ear peduncles enable them to keep their viability for a longer period of storage compared with threshed grains e.g. storage of maize grains as cobs (un-threshed) (1) or storage wheat grains in their ears grains without threshing $(7,14,15)$. Spikes and seeds of many wheat genotypes may differ in their size, weight and density due to the production environment and agronomic practices $(4,13)$. The genetic variation is the main cause of wheat varietal differences in terms of vegetative and reproductive characters which highly affected by genetic and environmental factors surrounding the plants during their growth period which has led to wheat varietal differences in the length and size of spike (3). Falih et al. (8) in their study of five wheat varieties (Abu-Ghraib, Latifiya, IPA-99, Tamouz and local wheat (control)), found that IPA-99 gave the highest spike length with no significant differences between Abu-Ghraib and Latifiya. Similarly, AL-Karim et al. (2) in their study of six wheat varieties (IPA-99, Iba95, Abu-Ghraib-3, Fatih, Tahaddi and Taqa-1), found significant differences between varieties with the superiority of Taqa- 1 in the spike length, number of grains spike ${ }^{-1}$ and grain yield of plant with no significant differences with IPA-99 in the spike length while Tahaddi gave the lowest averages of both characters. Similarly, Hassan and Baktash (11) and Baktash (5) found that significant differences between wheat varieties in the spike length, number of grains spike $^{-1}$, grain weight and grain yield of plant. The findings of previous researches confirmed the importance of wheat seeds storage in their spikes with the varietal differences in the seed size and spikes. However, these studies didn't refer to the storage characteristics of grains storage method in their spikes like the space size required by spikes and to which extent they can be gathered and compacted and what harms that may could result from such practices. Therefore, the present study was aimed to identify the storage characteristics of stored wheat spikes under different levels of compaction compared with threshed grains.

\section{MATERIALS AND METHODS}

A Laboratory experiment was carried out in the Seed Technology Laboratory, Department of Field Crops, College of Agricultural Engineering Sciences-University of Baghdad during 2017 and 2018. The objective was to identify the storage characteristics of spikes of five bread heat cultivars (Abu-Ghraib3, IPA99, Boohooth-22, Al-Rashid and Al-Wafeer) at moisture content $11.3 \% \pm 0.2 \%$ (Fig. 1). These varieties were seeded with $120 \mathrm{~kg} \mathrm{ha}^{-1}$ seedling rate during the 2016-2017 growing season at field crop research station. Un threshed wheat spikes were divided into five sections according to the space occupied by these spikes. Each division was placed in a carton cubic container $(25 \times 25 \times 25 \mathrm{~cm})$ which gave an area of $15625 \mathrm{~cm}^{3}$. The first division was threshed and other divisions were left to be compacted by adding different weight masses $\left(0,3,6\right.$ and $9 \mathrm{~kg}$ cubic $\left.^{-1}\right)$. The design of this experiment was completely randomized design (CRD). 


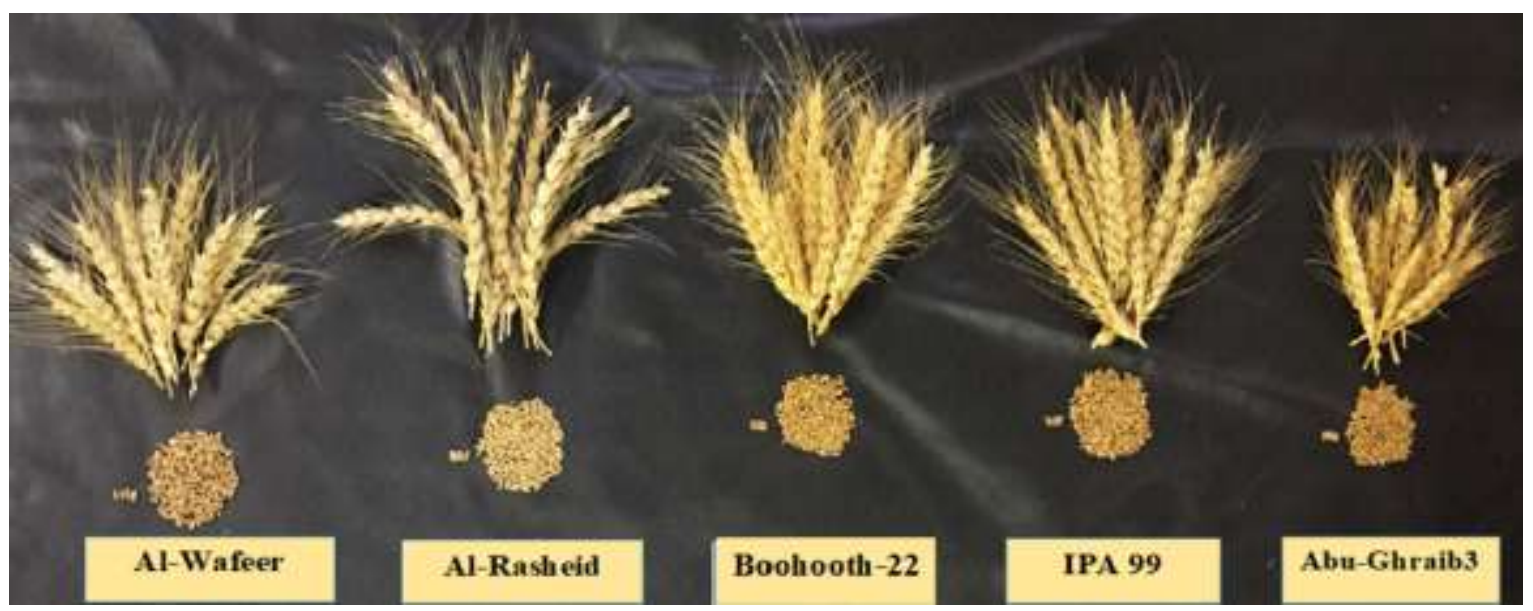

Fig. 1. Morphological of spikes for five wheat cultivars in this study.

\section{Studied characters}

Three samples were taken from each experimental unit consisted of 25 spikes to identify the spikes characteristics from these samples, spike length, spike diameter, weight of 250 grain $(\mathrm{gm})$, number of grain spike $^{-1}$, weight of grains spike $^{-1},(\mathrm{gm})$ and specific weight (weight of grains $/ 500 \mathrm{ml}$ ). Studied characters of compacted spikes after adding the weight masses in the cubic of $15625 \mathrm{~cm}^{3}$ $(25 \times 25 \times 25 \mathrm{~cm})$ were: Number of spikes (spike container $^{-1}$ counted from the spikes placed in the cubic containers). Percentage of broken spikes (\%) and number of dropped grains (grain container $^{-1}$ ): number of broken spikes were counted, then converted into percentages based on the cubic size, also the number of dropped grains were counted in each cube. Total grains weight of threshed spikes (gm) and the occupied space $\left(\mathrm{cm}^{3}\right)$ : spikes placed in each cube were threshed and weight. Area of each space occupied by threshed grains was estimated by using percentage and proportional method with each specific weight of each variety. Percentage of displacement in the container (\%): This character was measured by counting the displacement area after adding each weight mass on the gathered spikes in each cubic container.

\section{Statistical analysis}

Data were statistically analyzed a collected to the CRD design and the means were compared by using Least Significant Differences (LSD) (19).

\section{RESULTS AND DISCUSSION}

The results in Table 1 show significant differences between cultivars in all spikes and grains characteristics. Al-Rasheed cultivar gave the highest average spike length and less average of spike diameter $(16.17 \mathrm{~cm}$ and $1.33 \mathrm{~cm})$, respectively, without significant differences between Al-Rasheed and AlWafeer and Abu-Ghraib in the spike diameter, while the shortest spikes were for Abu-Ghraib $(8.17 \mathrm{~cm})$ which, also gave the lowest averages of 250 grains weight and grain weight spike $^{-1}$ (4.19 and $0.849 \mathrm{gm}$ ), without single spike $^{-1}$. Spikes of IPA-99 cultivar recorded the highest mean of spike diameter, number of grains and grains weight spike ${ }^{-1}$ $\left(1.63 \mathrm{~cm}, 55.39\right.$ grain spike ${ }^{-1}$ and $\left.1.773 \mathrm{gm}\right)$. Al-Wafeer cultivars recorded the highest average of 250 grains weight and specific

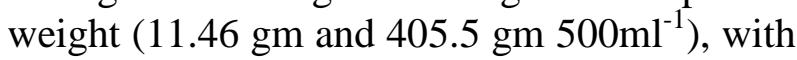
no significant differences with IPA-99 in the specific weight of grains. However, Tahaddi22, Al- Rasheed and Abu-Ghraib gave the lowest values of this character $(381.7,384.6$

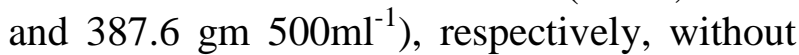
significant differences between them. This varietal differences may be due to their different genetic make-up which affects in the characters of spikes, grains and grain yield of each cultivar.

Table 1. Some characters of spikes and grains of cultivars.

\begin{tabular}{|c|c|c|c|c|c|c|}
\hline Cultivars & $\begin{array}{l}\text { Spike length } \\
\text { (cm) }\end{array}$ & $\begin{array}{c}\text { diameter } \\
\text { of spike } \\
(\mathrm{cm})\end{array}$ & $\begin{array}{l}\text { No. of grain } \\
\text { in spike }\end{array}$ & $\begin{array}{l}\text { Weight of } \\
250 \text { grain } \\
\text { (gm) }\end{array}$ & $\begin{array}{c}\text { Weight of } \\
\text { grain in spike } \\
\text { (gm) }\end{array}$ & $\begin{array}{c}\text { Weight } \\
\text { quality } \\
\text { (gm/500ml) }\end{array}$ \\
\hline Abu-Ghraib3 & 8.17 & 1.37 & 50.72 & 4.19 & $\begin{array}{l}0.849 \\
\end{array}$ & 387.6 \\
\hline IPA 99 & 14.33 & 1.63 & 55.39 & 8.00 & 1.773 & 405.2 \\
\hline Boohooth-22 & 10.33 & 1.42 & 41.22 & 5.41 & 0.892 & 381.7 \\
\hline Al-Rasheed & 16.17 & 1.33 & 46.07 & 7.42 & 1.367 & 384.6 \\
\hline Al-Wafeer & 11.17 & 1.36 & 37.21 & 11.46 & 1.705 & 405.5 \\
\hline LSD $_{0.05}$ & 1.55 & 0.06 & 2.78 & 0.24 & 0.062 & 12.5 \\
\hline
\end{tabular}




\section{Number of spikes}

Results of Table 2 refer to significant differences among cultivars in the number of spikes, where Abu-Ghraib had the highest average (763 spike container ${ }^{-1}$ ). While IPA-99 recorded the lowest (575 spike container ${ }^{-1}$ ) with no significant differences with Boohooth22. This may be due to the small length of spikes of Abu-Ghriab3 compared to the spikes of IPA-99 on spikes length of IPA-99 was taller by $6 \mathrm{~cm}$ than Abu-Ghraib3 spikes, besides the spike diameter of IPA-99 was larger (Table 1). It is also clear from Table 2 that increasing pressure on the spikes gather in the cubic container by increasing weight masses has led to increase the size of

Table 2. Effect of level of weight presser levels on the displacement on the spikes number and the broken spikes percentages

\begin{tabular}{|c|c|c|c|c|c|c|c|c|c|c|}
\hline \multirow{3}{*}{ Cultivars } & \multicolumn{5}{|c|}{ spikes No. $\left(\right.$ spike container ${ }^{-1}$ ) } & \multicolumn{5}{|c|}{ broken spikes percentage (\%) } \\
\hline & \multicolumn{4}{|c|}{ 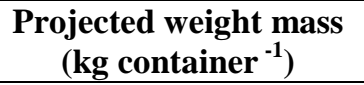 } & \multirow[t]{2}{*}{ Mean } & \multicolumn{4}{|c|}{$\begin{array}{l}\text { Projected weight mass } \\
\left(\text { kg container }^{-1}\right)\end{array}$} & \multirow[t]{2}{*}{ Mean } \\
\hline & $\mathbf{0}$ & 3 & 6 & 9 & & 0 & 3 & 6 & 9 & \\
\hline Abu-Ghraib3 & 473 & 717 & 877 & 987 & 763 & 0.00 & 0.49 & 1.27 & 2.18 & 0.99 \\
\hline IPA 99 & 371 & 571 & 625 & 734 & 575 & 0.00 & 1.08 & 2.97 & 3.59 & 1.91 \\
\hline Boohooth-22 & 364 & 539 & 722 & 758 & 596 & 0.00 & 2.02 & 2.84 & 3.48 & 2.08 \\
\hline Al-Rasheed & 289 & 851 & 578 & 757 & 619 & 0.00 & 5.88 & 8.30 & 9.00 & 5.80 \\
\hline Al-Wafeer & 408 & 648 & 693 & 894 & 661 & 0.00 & 3.18 & 6.54 & 6.37 & 4.02 \\
\hline LSD 0.05 & \multicolumn{4}{|c|}{54} & 27 & \multicolumn{4}{|c|}{0.54} & 0.27 \\
\hline Mean & 381 & 665 & 699 & 826 & & 0.00 & 2.53 & 4.38 & 4.93 & \\
\hline LSD 0.05 & & & 24 & & & & & 0.24 & & \\
\hline
\end{tabular}

\section{Broken spikes percentage}

It is clear from Table 2 that there were significant varietal differences in this character, where Abu-Ghraib3 was gave the lowest value of broken spikes percentage $(0.99 \%)$, compared with $5.8 \%$ for Al-Rasheed cultivar. This could be attributed to the spike length which might increase their proness to the breaking as the tall the spike the more breaking. This was noted in Table 1, where spikes of Al-Rasheed were the tallest compared with other cultivars. Also, increasing the pressure via increased the weight masses on the spikes was accompanied in a significant increase in the broken spikes percentages from $0.00 \%$ under no pressure to the $4.93 \%$ at $9 \mathrm{~kg}$ container ${ }^{-1}$ pressure while Al-Rasheed under $9 \mathrm{~kg}$ container ${ }^{-1}$ gave the highest percentage of broken spikes $(9.00 \%)$. At the beginning of the experiment execution, there were no broken spikes where they were removed in the control treatment, but after putting the pressure, breaking of spikes occurs displacement and hence saving more space to contain more spikes which was 381 spike container $^{-1}$ without putting pressure $(0 \mathrm{~kg}$ container $^{-1}$ ) on spikes to reach the highest average (826 spike container $\left.{ }^{-1}\right)$ under the pressure $9 \mathrm{~kg}$ container $^{-1}$. The interaction between cultivars and weight masses shows significant differences, where Abu-Ghriab3 at $9 \mathrm{~kg}$ container $^{-1}$ had the highest value (987 spike container ${ }^{-1}$ ) compared with 289 spike container $^{-1}$ for Al-Rasheed under no pressure $\left(9 \mathrm{~kg}\right.$ container $\left.{ }^{-1}\right)$. This could due to the small sizes of Abu-Ghriab3 compared with other cultivar, particularly. Al-Rasheed which its spikes lengths were the tallest (Table 1$)$.= where Al-Rasheed was more vulnerable to the breaking due to its tall spikes.

Number of shuttered grains

Results of Table 3 show varietal differences, weight masses level and their interaction. Spikes of Abu- Ghraib3 recorded the lowest average of shuttered grains (36.58 grain container $\left.^{-1}\right)$ compared with (114.7 grain container $^{-1}$ ) for Al-Rasheed cultivar. This may be attributed that spikes of Abu-Ghraib3 were short with compared and rigid glumes which, ultimately, reduced the number of broken spikes (Table 2) compared with other cultivars with loose and uncompacted glumes which increased the percentages of broken spikes (Table 2), and consequently increased the number of shuttered grains. It is also clear from the same Table that increased pressure on displacement spikes has accompanied by increased number of shuttered grains from spikes where it was the lowest value ( 9.0 grain container $^{-1}$ ) under no pressure compared with 144.3 grain container $^{-1}$ under the highest 
increased percentages of broken as a result of increase pressure on spikes (Table 2), an hence, increased shuttered grains. The interaction between Abu-Ghraib3, IPA-99, Boohooth-22 and Al-Wafeer Cultivars with no pressure gave the lowest average of shuttered grains (3.0, 4.0, 7.7 and 12.3 grain container $\left.{ }^{-1}\right)$, respectively without significant differences between them. However, Al-Rasheed under the highest pressure $9 \mathrm{Kg}$ container $^{-1}$ recorded the highest number of shuttered grains (12.0 grain container $\left.{ }^{-1}\right)$. The decreased number of shuttered grains in the control treatment (no pressure on spikes) reflects the normal status of spikes per cultivars except for Al-Rasheed which has the highest number of shuttered grains and with putting pressure on its spikes the number of shuttered grains was increased. This considered one of the Al-Rasheed disadvantage. The situation was vice versa for Abu-Ghraib3.

Table 3. Effect of level of weight presser levels on the displacement on shuttered grains and weight of total grain

\begin{tabular}{|c|c|c|c|c|c|c|c|c|c|c|}
\hline \multirow{3}{*}{ Cultivars } & \multicolumn{5}{|c|}{ shuttered grains (grain container $^{-1}$ ) } & \multicolumn{5}{|c|}{ total grain weight of spike (gm container ${ }^{-1}$ ) } \\
\hline & \multicolumn{4}{|c|}{ 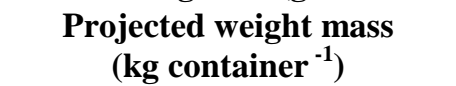 } & \multirow[t]{2}{*}{ Mean } & \multicolumn{4}{|c|}{$\begin{array}{l}\text { Projected weight mass } \\
\left(\text { kg container }^{-1}\right)\end{array}$} & \multirow[t]{2}{*}{ Mean } \\
\hline & $\mathbf{0}$ & 3 & 6 & 9 & & $\mathbf{0}$ & 3 & 6 & 9 & \\
\hline Abu-Ghraib3 & 3.0 & 17.7 & 51.0 & 74.7 & 36.58 & 401 & 609 & 744 & 838 & 648 \\
\hline IPA 99 & 4.0 & 52.0 & 94.0 & 116.3 & 66.6 & 658 & 1012 & 1109 & 1301 & 1020 \\
\hline Boohooth-22 & 7.7 & 47.7 & 91.3 & 119.0 & 66.4 & 325 & 480 & 644 & 676 & 531 \\
\hline Al-Rasheed & 18.0 & 104.0 & 142.0 & 216.3 & 120.1 & 395 & 1163 & 790 & 1035 & 846 \\
\hline Al-Wafeer & 12.3 & 82.3 & 102.3 & 195.0 & 98.0 & 696 & 1104 & 1181 & 1524 & 1126 \\
\hline LSD 0.05 & \multicolumn{4}{|c|}{10.1} & 5.1 & \multicolumn{4}{|c|}{65} & 33 \\
\hline Mean & 9.0 & 60.7 & 96.1 & 144.3 & & 495 & 874 & 893 & 1075 & \\
\hline LSD 0.05 & & & 4.5 & & & & & 29 & & \\
\hline
\end{tabular}

\section{Total spikes grain weight}

There were significant differences among cultivars, level of pressure imposed on displacement spikes and their interaction (Table 3). Grains of Al-Wafeer had the highest average (1126 gm displacement ${ }^{-1}$ ) compared with the lowest one (513 $\mathrm{gm}$ displacement $^{-1}$ ) for Boohooth-22. This may be attributed that grains of Al-Wafeer gave the highest weight of 250 grains, and specific weight compared with Boohooth-22 cultivar which recorded the lowest averages (Table 1). The increase of pressure imposed on spikes has led to increase in the weight of threshed grains to reach the highest level $(1075 \mathrm{gm})$ at the highest level of pressure ( $9 \mathrm{~kg}$ container ${ }^{-1}$ ) compared with 495 gm for non pressure treatment (Table 3 ). This could be due to the superiority of high pressure treatment ( $9 \mathrm{~kg}$ container $\left.{ }^{-1}\right)$, which had the highest number of spikes compared with other pressure treatments and control which gave the lowest average (Table 2). The interaction between Al-Wafeer cultivar and high pressure level $\left(9 \mathrm{~kg}\right.$ container $\left.^{-1}\right)$, recorded the highest value (1524 gm) compared with $325 \mathrm{gm}$ for Boohooth-22 and non pressure treatment.

Displacement in container percentage

Results of Table (3) show significant varietal differences as influenced by pressure levels and their interaction. The largest displacement occurred for Al-Rasheed (44.42\%) compared with the lowest one (31.25 and $33.00 \%)$ for IPA-99 and Abu-Ghraib3, respectively. This varietal differences could be due to their different genetic make-up on Al-Rasheed was characterized by its longest spikes and less diameter compared with other cultivars, esp. Abu-Ghraib3 which had the shortest spikes (Table 1), therefore, the interspace between long spikes were larger than small spikes. Results of Table 3 indicate that the displacement in containers with the increasing of pressure levels from $0.00 \%$ at no pressure to $54.67 \%$ at the increasing of pressure level (9 $\mathrm{kg}$ container $\left.^{-1}\right)$. For interaction, spikes of AlRasheed at $9 \mathrm{~kg}$ container $^{-1}$ recorded the highest average $(66.00 \%)$. While $3 \mathrm{~kg}$ container $^{-1}$ imposed on spikes, cultivars Boohooth-22, Abu-Ghraib3 and IPA-99 gave the lowest percentages of displacement (32.39, 34.00 and $35.00 \%$ ). It is worth while to mention that Al-Rasheed gave the highest percentage of displacement at $3 \mathrm{~kg}$ container $^{-1}$ compared with other cultivars at the same level of pressure. This may be due to the tallest spikes and less diameter of Al-Rasheed spikes as mentioned before. Additionally, most spikes of Al-Rasheed are not-erect which in turn 
reduces the spikes number in the container (Table 2) and increased the resulted space as a result of pressure because of reducing the spaces among spikes of this variety.

Table 4. Effect of level of weight presser levels on the displacement on replacement percentage in the container and replacement in grains space resulted from spikes

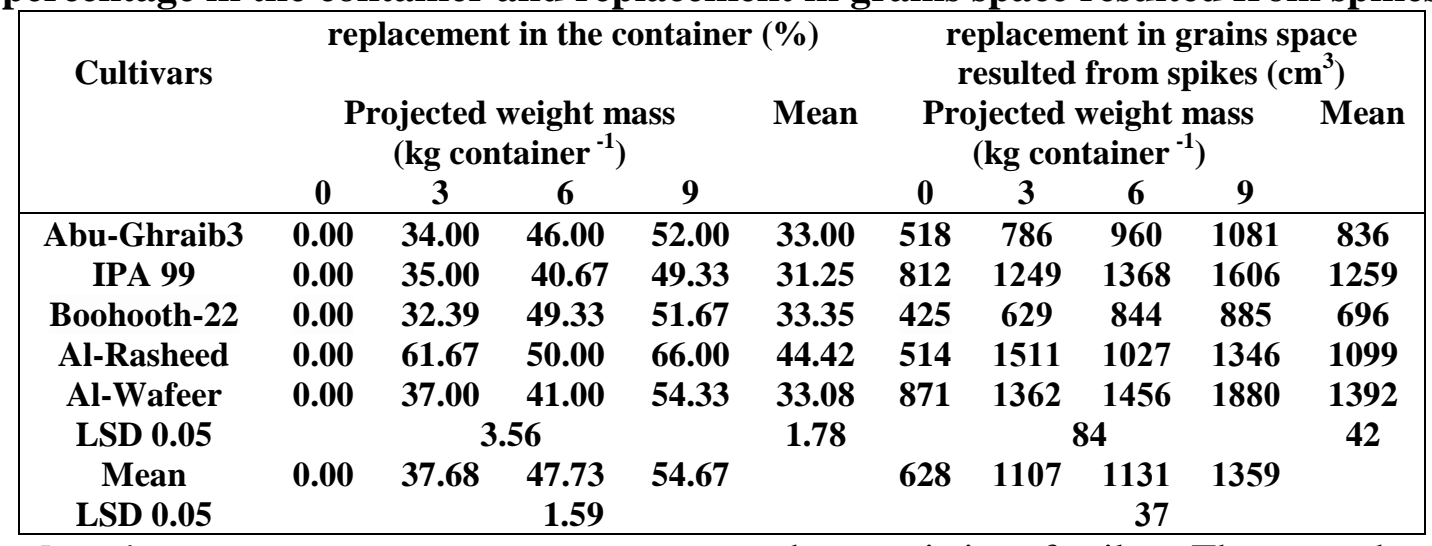

\section{Threshed grains space}

Results Table 3 reveal that were varietal differences, pressure levels and their interactions. Grains of Al-Wafeer had the highest average $1392 \mathrm{~cm}^{3}$ compared with 699 $\mathrm{cm}^{3}$ for the grains of Bohooth-22. This could be due that grains of $\mathrm{Al}-\mathrm{Wafeer}$ recorded the highest average of specific weight compared with the lowest one for Bohooth-22 grains (Table 1). Also, the pressure levels imposed on spikes has led to increased the space of threshed grains from $628 \mathrm{~cm}^{2}$ at control to $7219 \mathrm{~cm}^{2}$ at the highest pressure level $(9 \mathrm{~kg}$ container $^{-1}$ ) (Table 3 ). This could be due to the increased spikes number occupied the whole container $\left(15625 \mathrm{~cm}^{3}\right)$ to reach $53.80 \%$ increase compared with zero pressure (Table 3) Concerning interaction' Al-Wafeer at the highest pressure $9 \mathrm{~kg}$ container $^{-1}$ gave the highest average $\left(1880 \mathrm{~cm}^{3}\right)$ compared with the lowest value $\left(425 \mathrm{~cm}^{3}\right)$ for Bohooth-22 at no pressure. This result could be due to the effect of both study factors as a single or combined in giving the highest total grains weight (Table 3 ). From the results of this experiment could be concluded that storing of wheat grains as spikes is of paramount importance which protects from insects and diseases infections and maintains their viability for a longer period, besides, it is friendly method to the environment $(7,14,15)$. Therefore, studying storage characteristics of wheat spikes is complementary to the previous studies. It was revealed from the present study that wheat varieties differed in their storability as accumulation which can be attributed to the genotype effect on the morphological characteristics of spikes. The most shortest and compared spikes the less losses resulted from the spikes pressure. It was noted in the spikes of Abu-Ghraib3 compared with more losses in Al-Rasheed spikes as they were taller and loose with lowest diameter. The losses in AlRasheed were high percentages of broken spikes, shuttered grains and less spikes in the containers which, in turn, increased the size of displacement resulted from their spikes pressure. Also, it was found that the lowest level of pressure $\left(3 \mathrm{~kg}\right.$ container $\left.^{-1}\right)$ can offer a good and acceptable result in reducing the area of space that could be occupied spikes and reducing the losses resulted from that level of pressure despite the superiority of high pressure levels effect on these characters, yet, the difference was less compared with the high difference between $3 \mathrm{~kg}$ container $^{-1}$ and control. The results values.

\section{REFERENCES}

1. Ali, A.G. 2007. Evaluation of Treasury Susceptibility of Seeds and Germs of Varieties of Maize (Zea mays L.) Stored With Moisture Contents and Different Storage Periods. Ph.D. Dissertation, Agriculture College, University of Baghdad. pp:121

2. AL-Karim, I.K.A. 1997. Changes Occurring in Rice Seed (Oryza sativa L.) During Storage. MSc Thesis, Agriculture College, University of Baghdad. pp:80

3. Alnori, M. A. and R.F. Al-Obady. 2013. Effect of seed size and plants spacing in grain quality of two synthetic varieties of corn ( $\mathrm{Zea}$ mays L.). Tikrit J. for Agric. Sci.,13(2):287297 
4. Amer, S.A.A. 2004. Response of some Bread Wheat Cultivars Triticum aestivum L. to Water Stress Under Field Conditions. Ph.D. Dissertation, Agriculture College, University of Baghdad. pp:142

5. Baktash, F. Y. 2016. Genotypic stability for some bread wheat pure lines. The Iraqi J. of Agric. Sci., 74: (Special Issue): 47-52.

6. Belderak, B., H. Mesdag and D. A. Donner. 2000. Bread-Making Quality of Wheat. New York: Springer, pp:416

7. Cheyed, S.H. 2019. Field emergence and seedling vigour of bread wheat as influenced by method and longevity of storage. The Iraqi J. of Agric. Sci., 50(6):1495-1500.

8. Falih, T.F., S. W. Jaber and K. H. Mohsen. 2015. Comparison of four varieties of wheat Triticum aesstivum L. with local wheat under climate of southern Iraq. Basrah J. of Agric. Sci., 28(2):98-105.

9. FAO. 2015. Food and Agriculture Organization of the United Nation, Statistics Divison, From URL, http://faostat3.fao.org/browse/Q/QC/

10. FAO. 2019. Archived from the original on 7 October 2019. Crops/World Total/ Wheat/ Area Harvested/2019 (pick list)". United Nations

11. Hassan, L. K. and F. Y. Baktash. 2014.Genetic variability, heritability and trait associations in bread wheat genotypes. The Iraqi J. of Agric. Sci., 45(8) (Special Issue): 822-835.

12. Jones, J. M., R. J. Peña, R. Korczak, and H.J. Braun. 2015.Carbohydrates, Grains, and Wheat in Nutrition and Health: An Overview Part I. Role of Carbohydrates in Health ${ }^{1,2}$. Cereal Foods World. 60(5):224-233
13. Kadom, M. N. and K. A. Jaddoa. 2016. Effect of regulation of source-sink relationship on spike growth rate and dry matter acumuilation for different wheat cultivars. The Iraqi J. of Agric. Sci., 47(2): 461-477

14. Karaoglu, M.M., Aydeniz, M., Kotancilar, H. G. and K. E. Gercelaslan. 2010. A comparison of the functional characteristics of wheat stored as grain with wheat stored in spike form. Int. J. of Food Sci. and Tech. 45, 38-47

15. Said, M.K.H. 2019. Effect of the Wheat Seeds Storage Method and Period on Severity of Infestation by Khapra Beetle and Red Flour Beetle. M.Sc. Thesis, Collage of Graduate Studies- Sudan University of Science Technology. pp:105.

16. Salim, H. A. and S. J. Mahdi. 2012. Effect of tillage and chemical herbicides on the control of weeds in wheat crop. Karkok Univ. J. for Agric. Sci. 3(2) :87-104

17. Shewry, P. R. and S. J. Hey. 2015. Review: The Contribution of Wheat to Human Diet and Health. Food and Energy Security. 4 (3): 178-202

18. Šramkováa, Z., E. Gregováb and E. Šturdík. 2009. Chemical composition and nutritional quality of wheat grain. Acta Chimica Slovaca, 2(1):115 - 138

19. Steel, R. G., J. H. Torrie and D. A. Dickey .1997. Principles and Procedures of Statistics, a Biometrical Approach, McGraw Hill Book, Singapore, $3^{\text {rd }}$ ed., McGraw Hill Book, Int. Co., New York, US. pp:352-358

20. Thamaga-Chitja, J.M., S.L. Hendriks, G.F. Ortmann and M. Green. 2004. Impact of maize storage on rural household food security in northern Kwa Zulu Natal, Journal of Family Ecology and Consumer Science 32: 8-15. 